\title{
温度刺激下におけるヒト直立姿勢の解析
}

\author{
金谷健史・白戸勝・海野徳二
}

\section{Analysis of Postural Change During Caloric \\ Stimulation in Man}

\section{Takeshi Kanaya, Masaru Shirato and Tokuji Unno}

(Asahikawa Medical School)

\begin{abstract}
Postural change was analyzed during unilateral and bilateral caloric stimulation with ice water. During stimulation the normal subject was asked to maintain an upright position on a platform. Postural change was divided into postural deviation and body sway by a digital filter with reference to the power spectrum of the DC record. Right forward postural deviation and increased right-left and anteriorposterior body sway were observed during right caloric stimulation. Forward postural deviation and increased anterior-posterior body sway were observed during bilateral caloric stimulation. These results suggest that the neuronal mechanism of postural deviation and of body sway is not the same.
\end{abstract}

\section{は じめに}

ヒトの直立姿勢はおもに体性感覚系, 視覚系, 前庭系からの適確な情報が姿勢調節機構に伝達さ れることにより安定な系として維持されていると考えられる。したがって一側または両側前庭障害 時に認められる直立姿勢の異常は, 前庭系からの情報が破綻し, 安定な系が不安定な系へ移行した 結果と考えることができる. 本研究で我々は迷路に対する温度刺激下にヒト直立姿勢を解析し, 前 庭障害時に認められる直立姿勢異常の神経生理学的メカニズムを明らかにしよらと試みた。

\section{方}

実験は正常被検者 7 名で行なった，直立姿勢 の変化は, キスラー社の重心動摇計により検出 し，X軸成分（左右方向の動き）と $\mathrm{Y}$ 軸成分（前 後方向の動き）をとれぞれ解析した。 また姿勢 変化に伴ら下肢筋活動を評価する目的で, 左右 ヒラメ筋および前弳骨筋からの表面筋電を同時 記録した。温度刺激は $0^{\circ} \mathrm{C}, 20 \mathrm{cc}, 10$ 秒間注水 法を用い，一側注水㧍よび両側同時注水を開眼

\section{法}

直立姿勢, 閉眼直立姿勢のそれぞれについて行 なった。 また同時に水平および垂直方向の眼球 運動を $\mathrm{ENG}$ 記録し, 両側同時注水は水平方向 の眼振が出現しない例のみを解析の対象とした。 重心動摇計の出力はデーターレコーダーに収 録し20msecで AD変換した後, マイクロコン ピューターを用いて振幅ヒストグラム, 周波数 解析扣よびフィルター処理を行なった。 
結

(1) 閉眼直立時, 右側温度刺激

図 1 に閉眼直立, 右側温度刺激時の姿勢変化 の記録と下肢笳活動記録の代表例を示す．注水
果

終了後，右方向と前方向へゆっくりとした重心 移動が起こり，左右方向と前後方向記録の振幅 増大を認めた。 左右, 前後方向の振幅増大は,

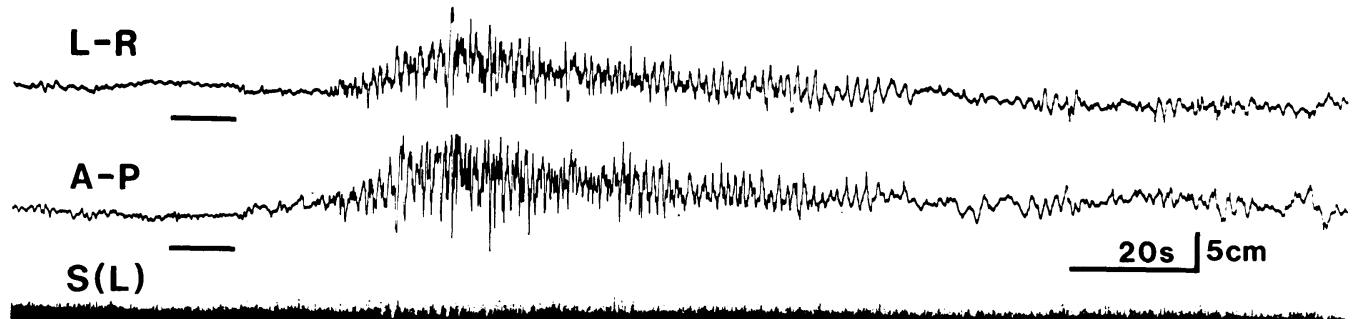

TA(L)

$S(R)$

$T A(R)$

図 1 闒眼直立時, 右側温度刺激の記録

$\mathrm{L}-\mathrm{R}$; 重心動摇計，左右方向の記録（右方向が上）

$\mathrm{A}-\mathrm{P}$; 重心動摇計, 前後方向の記録（前方向が上）

$\mathrm{S}(\mathrm{L}), \mathrm{S}(\mathrm{R})$; 左右七ラメ筋, 筋電図

$\mathrm{TA}(\mathrm{L}), \mathrm{TA}(\mathrm{R})$; 左右前脛骨筋, 筋電図

温度刺激の期間は $\mathrm{L}-\mathrm{R}, \mathrm{A}-\mathrm{P}$ 記録下の黑線で示した。

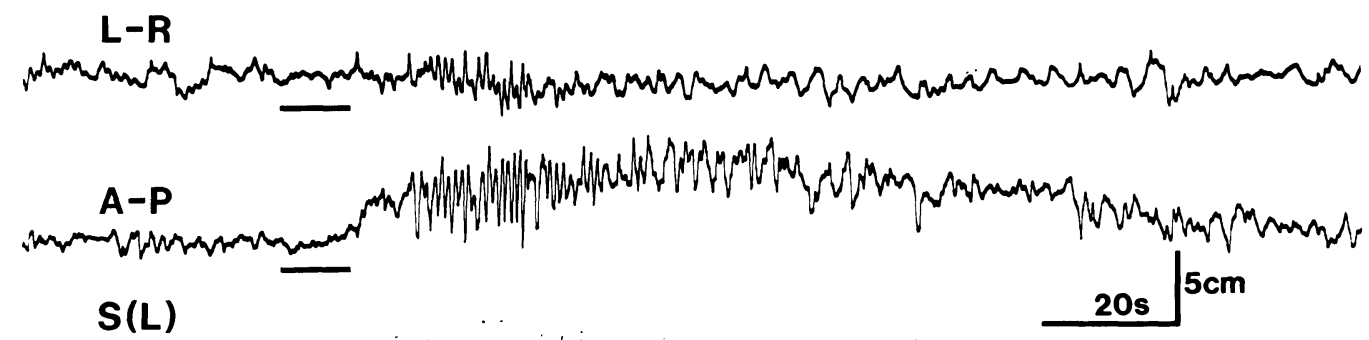

$\mathrm{TA}(\mathrm{L})$

$\mathbf{S}(\mathbf{R})$

TA(R)

図 2 閉眼直立時, 両側温度刺激の記録 
注水開始 30 秒前後から約 80 秒間持続し, 徐々 に刺激前の状態にもどった，下肢伸筋である七 ラメ筋は, 左右方向の重心移動にほぼ一致して 左側では活動の減少を，右側ではその増加を認 めた。また安静直立時には出現しない左右下肢

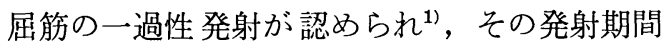
は左右, 前後方向の振幅増大時にほぼ一致して いた。

(2) 閉眼直立, 両側同時温度刺激

図 2 に閉眼直立, 両側同時温度刺激時の姿勢 変化の記録と下肢筋活動記録の代表例を示す。 注水終了後, 前方向へゆっくりとした重心移動 が起こり，前後方向記録の振幅増大が認められ た. 前後方向の振幅増大は注水開始 20 秒後から
約 60 秒間持続し, 徐々に刺激前の状態にもどっ た。一側温度刺激の場合と同様に, 左右下肢屈 筋が前後方向記録の振幅増大時に一過性の発射 活動を示した.

\section{（3）重心位置の移動と身体動摇}

閉眼直立時に一側および両側温度刺激で得ら れた左右 (LR) 方向と前後 (AP) 方向の記録 から，それぞれ刺激開始20秒前より20秒間ごと に経時的振幅ヒストグラムを作製し図 $3 ， 4$ に 示した. ヒストグラムの分散増加は身体動摇の 増加を意味する．また各ヒストグラム内の白丸 は単位時間ごとの平均值であり，20秒間の平均 的重心位置と考えることができる. 一側温度刺 激（図 3 ）では刺激開始40～60秒後に重心位置

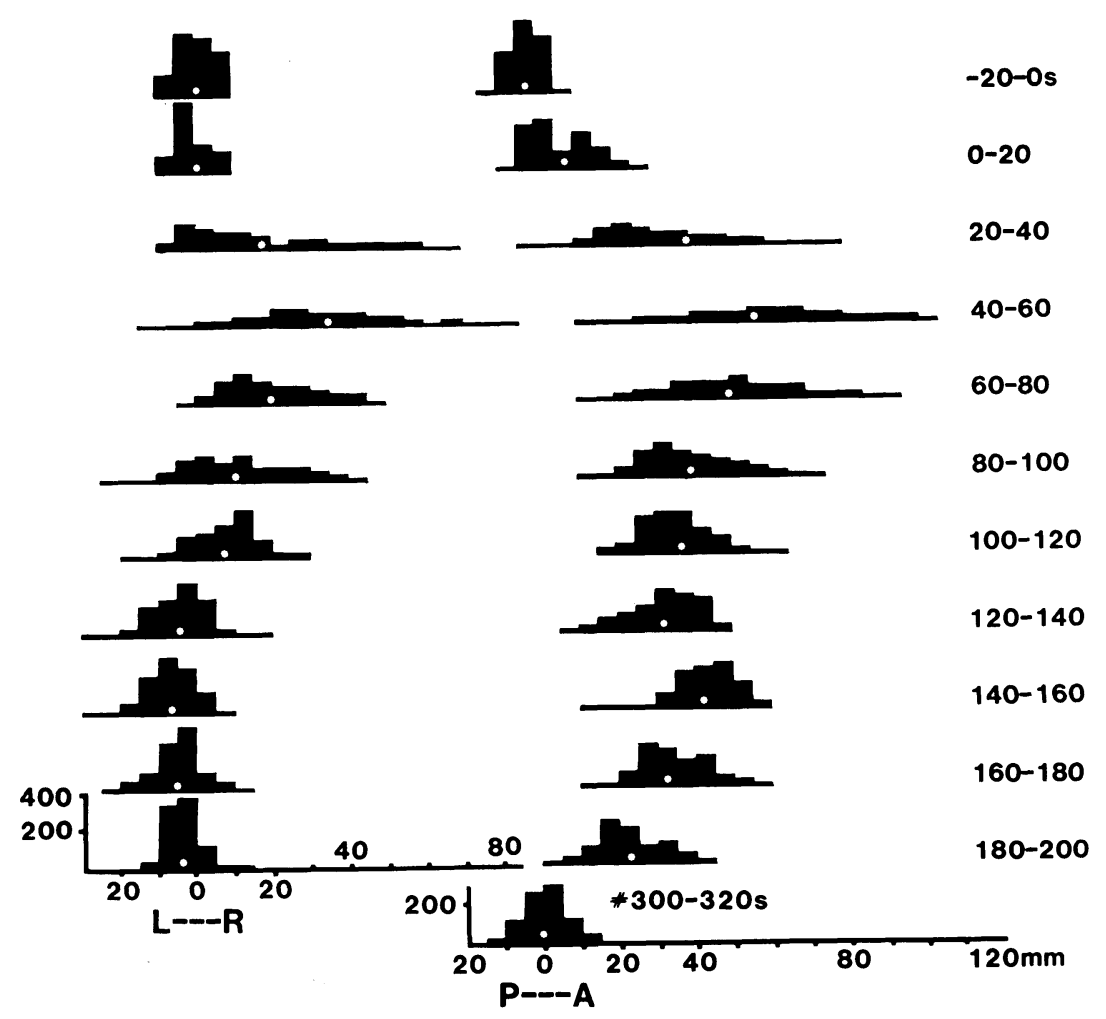

図 3 閉眼直立時, 右側温度刺激の経時的振幅ヒストグラム

図左は左右方向，右は前後方向の振幅ヒストグラムである．ヒストグラムの 縦軸は度数，横軸は刺激前 20 秒間の平均值を 0 とし，左右方向，前後方向を mmで表わしている.

図右 $0 \sim 20$ は刺激開始 $0 \sim 20$ 秒を示す. 

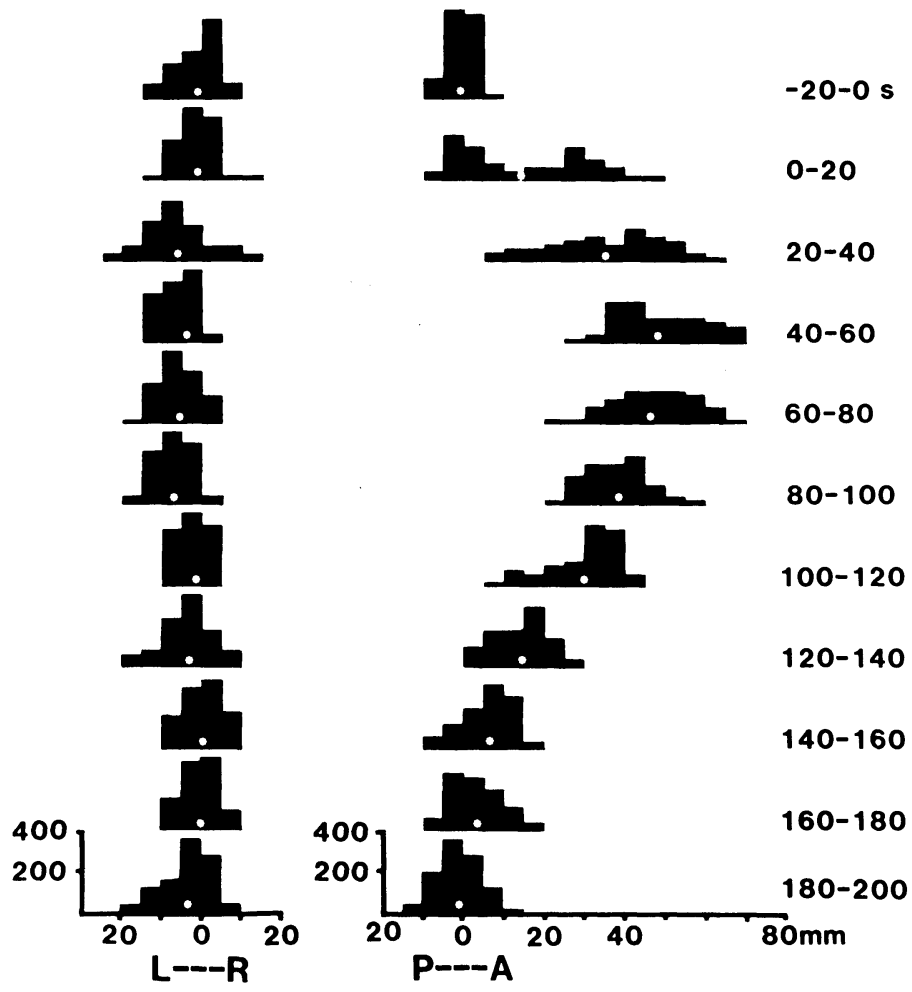

図 4 閉眼直立時, 两側温度刺激の経時的振幅ヒストグラム

は右前方向（右 $3.7 \mathrm{~cm}$, 前 $5.6 \mathrm{~cm}$ ) へ移動し, 身体動摇は LR, AP 万向とも最大となった. LR 万向に関しては重心位置，身体動摇とも注 水開始 200 秒後にほぼ注水前の状態へもどった が，AP 方向に関してのそれは 5 分後に注水前 の状態にもどった。一方両側温度刺激では図 4 に示す様に, LR 方向の重心位置の移動および 身体動摇の増加をほぼ認めず， AP 方向のみ重 心位置の移動（最大 $4.8 \mathrm{~cm}$ ）と身体動摇の増加 を認めた。

（4）重心の偏倚と動摇

一側および両側温度刺激下における直立姿勢 の変化を振幅ヒストグラムにより解析すると, 刺激に対応した重心位置の移動と身体動摇の増 加といら 2 つ現象がともに認められることが 明らかとなった。我々は, 前者の様な遅い周波 数成分をもつ重心位置の移動を偏倚と，また後 者の様な比較的速い周波数成分をもつ重心の摇
れを動摇と考光，デジタルフィルターを用いて 両者の分離を試みた。図 5 は一側刺激の例を, 図 6 は両側刺激の例を示す。両図とも上段より $\mathrm{LR}, \mathrm{AP}$ 万向の DC 記録 (原波形), LR, AP 方向の $0.15 \mathrm{~Hz}$ hi-cut 記録（偏倚波形）, LR, AP 方向の $0.15 \mathrm{~Hz}$ low-cut 記録（動摇波形） である。この様に原波形を偏倚波形と動摇波 形に分離することにより，一側刺激では重心の 偏倚と動摇增加は LR 方向および AP 方向と もほぼ同様の時間経過と大きさで起こり，両側 刺激では重心の偏倚と動摇増加は AP 方向に 著しく認められることがより明らかに理解でき た.

今回得られた 7 人の成績を偏倚波形と動摇波 形に分離して解析すると，以下の結果が得られ た. 閉眼一側刺激において偏倚は LR 方向 AP 方向ともに認められ，最大偏倚の平均は LR 方 向 $3.7 \mathrm{~cm}$ であり AP 方向は $3.1 \mathrm{~cm}$ であっ 

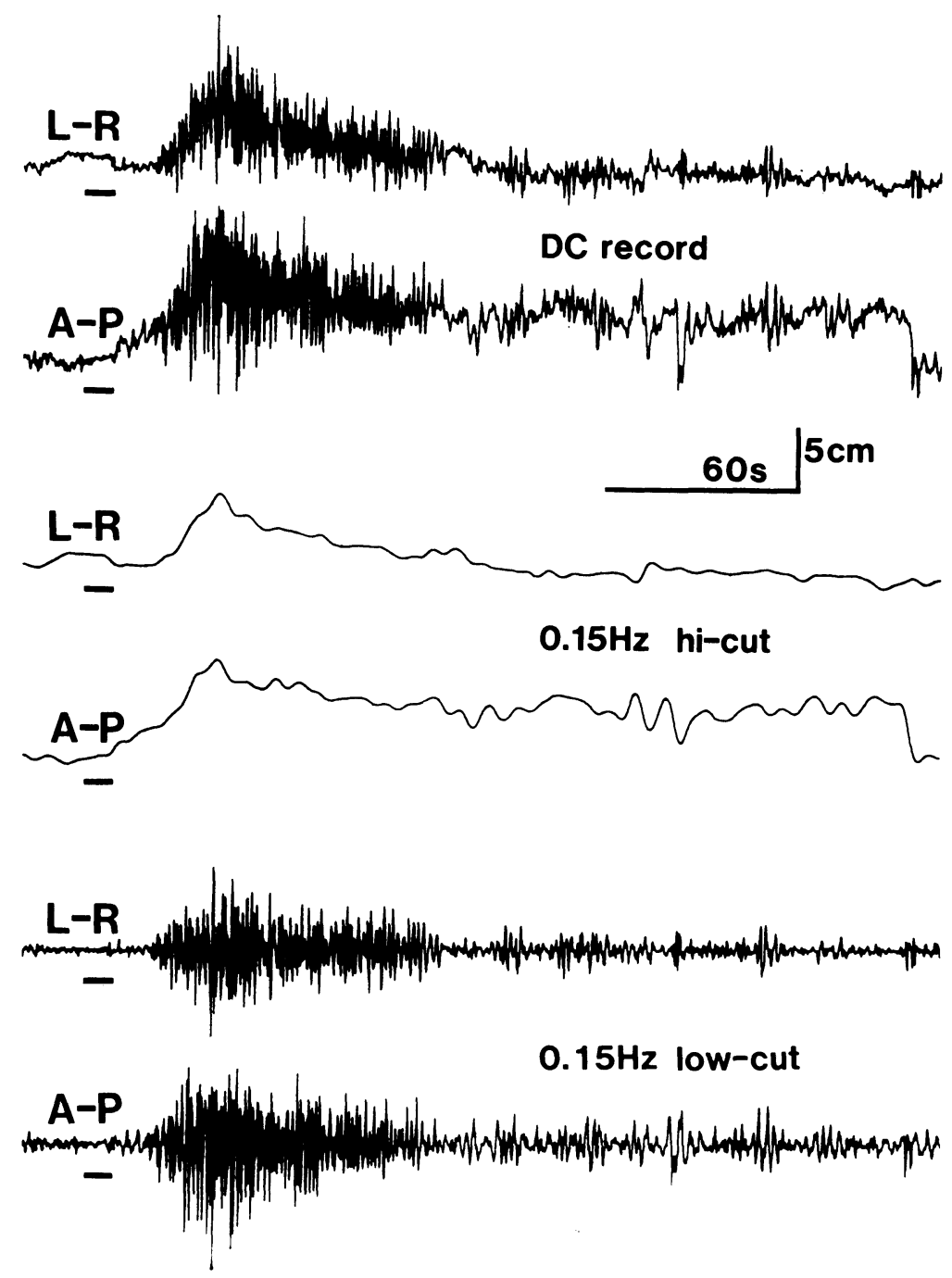

図 5 閉眼直立時, 右側温度刺激における原波形, 偏倚波形, 動摇波形

た. 動摇の増加も LR, AP 方向に認められ, 最大動摇の平均は $\mathrm{LR}$ 方向 $6.9 \mathrm{~cm}, \mathrm{AP}$ 方向 $7.5 \mathrm{~cm}$ であった。 閉眼両側刺激において偏倚 は AP方向のみに認められ，最大偏倚の平均は $4.9 \mathrm{~cm}$ であった。 また最大動摇の平均は $\mathrm{LR}$ 方向で $2.7 \mathrm{~cm}, \mathrm{AP}$ 方向で $6.3 \mathrm{~cm}$ と, AP 方

考

（1）温度刺激下に打忷る下肢筇活動について 下肢伸筋であるヒラメ筋は, 安静直立時にお
向の動摇が明らかに大きい結果となった．開眼 直立, 一側刺激時の場合も偏倚および動摇の増 加は LR, AP 方向ともに認められたが，いず れの例も閉眼時より著明に小さく, 開眼直立, 両側刺激時の場合は動摇の増加を認めず, AP 方向の偏倚のみ認められる例が多かった.

察

いて常に持続的発射活動を示すことが知られて いる. ${ }^{1)}$ 一側温度刺激により重心が刺激側に偏 


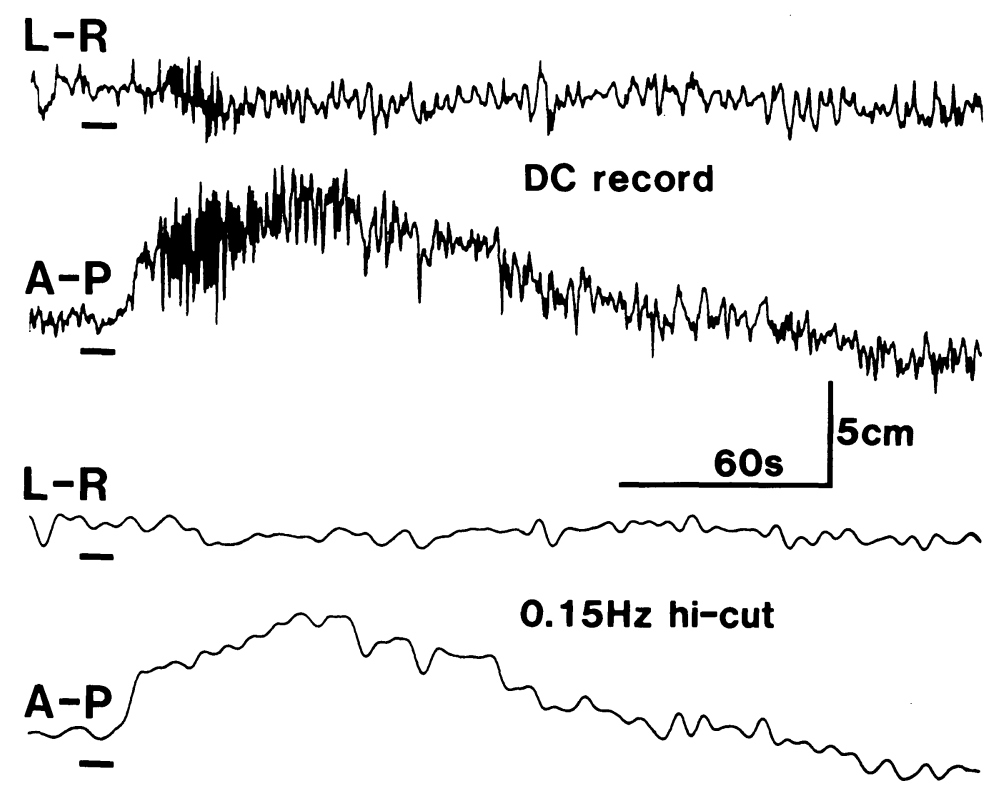

L-R

\section{$0.15 \mathrm{~Hz}$ low-cut}

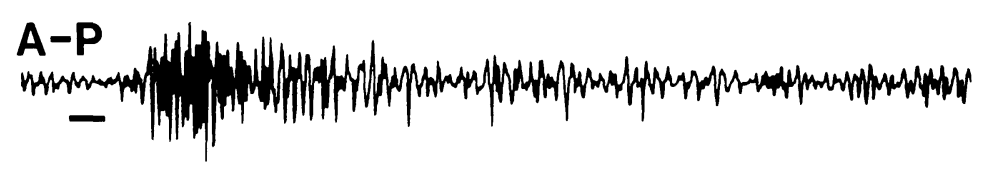

図 6 閉眼直立時, 両側温度刺激における原波形, 偏倚波形, 動摇波形

倚した際, 刺激側の伸筋活動が増大した今回の 成績より，少なくとも偏倚側の筋活動の減少が 直立姿勢の偏倚の原因ではないことが明らかと なった. 一方温度刺激による身体動摇の増加に 一致して屈筋活動が一過性に認められたのは, 伸屈筋の同時活動により足関節の動摇を最小に 保ち，5) 身体の転倒を防ぐメカニズムが中枢性 に脊髄運動細胞へ働いた結果と推定される.

（2）温度刺激下に拈ける重心の偏倚について 一側冷水刺激により直立姿勢の重心位置が刺 激側および前方向へ偏倚するといら報告は過去 にも認められる. 203) 一方両側冷水刺激により 直立姿勢の重心位置が前方向のみに偏倚すると
いら報告は我々が知る限りでは認められなかっ た. また前方向への偏倚が, 開眼直立, 閉眼直 立時の一側および両側温度刺激いずれの場合に も認められた成績は, 安定な直立姿勢が不安定 な直立姿勢に移行する際, 前方向の偏倚が出現 しやすいといら可能性を示唆した.

(3) 温度刺激下に打ける身体動摇の増加につ いて

今回の実験成績で我々は一側温度刺激では左 右方向, 前後方向の身体動摇はほぼ同様に増加 乙, 両側温度刺激では前後方向の身体動摇が左 右方向のそれに比べ明らかに大きいといら成績 を得た。両側迷路障害は前後型の動摇を示すと 
いら臨床成績は, ${ }^{4) 6)}$ 我々の両側温度刺激の成績 とよく一致するが，一側迷路障害者は左右型の 動摇を示すといら臨床成績と年6) 我々の一側温 度刺激の成績は一致しなかった。

（4）重心の偏倚と動摇について

直立姿勢の変化を, 重心の偏倚と動摇に分離 して解析する試みは過去にも報告されている. ${ }^{3)}$ 我々は原波形（DC 記録）のパワースペクトル を参考としてデジタルフィルターを用い, 0.1 $\mathrm{Hz} \sim 0.5 \mathrm{~Hz}$ まで約 $0.05 \mathrm{~Hz}$ ごとに原波形の hi-cut 処理および low-cut 処理を試みた. その 結果周波数解析上もまた視覚的にも, $0.1 \mathrm{~Hz}$ $0.2 \mathrm{~Hz}$ の間で偏倚波形と動摇波形を分離する ことが最も好ましいと考え, 今回は $0.15 \mathrm{~Hz}$ 以 下を偏倚成分, そして $0.15 \mathrm{~Hz}$ 以上を動摇成 分とした.ささらに回の実験成績を偏倚成分と 動摇成分に分離して検討すると, 開眼直立, 両
側温度刺激時の様に, 偏倚は生ずるが動摇の増 加が認められない例も存在し, 偏倚と動摇の増 加といら 2 つ現象がそれぞれ異なる神経機構 を介する可能性が示唆された。すなわら姿勢調 節機構に対する冷水刺激は, 一方では前庭器に 対する直接的刺激と考えられるが，他方では前 庭系入力の破綻による外乱と考えることができ る.これより我々は, 前庭器への刺激効果が姿 勢の偏倚を生じ, 外乱効果が身体動摇の増加を 生ずると考えた。臨床的にも末梢性めまいの発 作期には姿勢の偏倚と動摇増加が生じ, 非発作 期には偏倚のみ生ずる例があるが，これは直立 姿勢に対する前庭系の 2 つの効果すなわち刺激 と外乱という考方方を支持するものといえる. 今後臨床例に扣ける直立姿勢の異常を偏倚成分 と動摇成分に分離解析し，さらに検討を続ける 考えである。

\section{ま と め}

温度刺激下におけるヒト直立姿勢を重心の偏倚と動摇に分離解析し以下の結果を得た.

（1）直立姿勢を保った正常被検者に，一側冷水刺激を加えると，被検者の重心は注水側敃よび前方 向に偏倚し，また同時に前後，左右方向の身体動摇が増加した.

（2）両側同時冷水刺激を加えると, 被検者の重心は前方向のみに偏倚し, 閉眼時には前後方向の身 体動摇が増加した.

（3）重心の偏倚と動摇はそれぞれ異なった神経機構により生ずる可能性が示唆された。

\section{文}

1) Joseph J and Nightingale A: Electromyography of muscle of posture; Leg muscle in males. J Physiol $117:$ 484 491, 1952.

2 ）小町清彦: 外耳道冷水刺激の開眼直立姿勢に及ぼ す影響に関する研究. 名市大医誌 28: 1345 1358, 1978.

3 ) 三好豊二, 白戸 勝, 樋渡章二 : 重心の偏倚と動 摇. 日耳鼻 $80: 1011 \sim 1013,1977$.

4) 田口拓雄: 起立時身体動摇の研究. 耳鼻臨休 70 : 1065 1112, 1977.

\section{献}

5 ) 時田 喬, 宮田英雄, 藤垣 熙, 他：直立時身体 動摇の分析一動摇の多現象記録と相関分析によ る. 耳鼻臨床 63: 363 387, 1970.

6) Tokita T, Maeda M and Miyata $\mathrm{H}$ : The role of labyrinth in standing posture regulation. Acta Otolaryngol 91 : 521 527, 1981 .

別刷請求先 : 金谷健史 $\left(\begin{array}{l}\text { 干078-11 旭川市西神楽 } 4 \text { 線5-3-11 } \\ \text { 旭川医科大学耳鼻咽喉科学教室 }\end{array}\right)$ 